\title{
Australian Journal of Crop Science \\ Cultivation of common bean (Phaseolus vulgaris L.) subjected to shallow water table at riparian wetland in South Sumatra, Indonesia
}

\author{
Susilawati $^{1}$ and Benyamin Lakitan ${ }^{1,2^{*}}$
}

${ }^{1}$ College of Agriculture, Department of Agronomy, Universitas Sriwijaya, Inderalaya 30662, Indonesia

${ }^{2}$ Research Center for Sub-optimal Lands (PUR-PLSO), Universitas Sriwijaya, Palembang 30139, Indonesia

\section{*Corresponding author: blakitan60@unsri.ac.id}

\begin{abstract}
Common bean is a susceptible vegetable to excessive water condition in soil. Meanwhile, flooding occurrence and soil water table are unpredictable at riparian wetlands. These circumstances make cultivation of common bean in riparian wetland challenging. A field experiment was conducted at post flooding period but soil water table was still less than $30 \mathrm{~cm}$ below soil surface during transitional period from wet to dry season, in May to August 2017. Site location was a paddy field at Sungai Selincah Village, within riparian wetland ecosystem in South Sumatra, Indonesia. The paddy field is characterized by alluvial soil and periodically flooded for 4-6 months during rainy season. Raised beds were constructed for setting up water table positions at 10, 15, and $20 \mathrm{~cm}$ below soil surface. Results of this study indicated that common bean (Phaseolus vulgaris L.) could tolerate soil water table at depth of $15 \mathrm{~cm}$ or deeper without significant decrease in growth and yield. However, soil water table at depth of $10 \mathrm{~cm}$ significantly reduced plant height, number of trifoliate leaves, diameter of canopy, shoot dry weight, root length, number of primary lateral roots, chlorophyll content index $(\mathrm{CCl})$ during reproductive stage, total number of pods, and cumulative yield. In conclusion, it is possible to grow common bean at riparian wetland ecosystem as early as soil water table has subsided to $15 \mathrm{~cm}$ below soil surface during transitional period from wet to dry season.
\end{abstract}

Keywords: crop diversification; excess water; hypoxia; riparian wetland; stress recovery; tropical vegetable; sub-optimal land; waterlogging.

Abbreviations: CCI_chlorophyll content index; LSD_least significant difference; RBD_randomized block design; RLER_relative leaf expansion rate; WAP_week after planting.

\section{Introduction}

There are vast acreages of wetlands in the world. At global scale, Fan et al. (2013) estimated that shallow groundwater influenced 22 to $32 \%$ of global land area, including approximately $15 \%$ as groundwater-fed surface water features and 7 to $17 \%$ with the water table or its capillary fringe within plant rooting depths. In Indonesia, large acreages of wetlands are found in eastern coast of Sumatra Island, western and southern parts of Kalimantan Island, and southern part of Irian Jaya Island (Margono et al. 2014). However, at present, most of the wetlands in Indonesia have not been intensively utilized for agriculture, especially at riparian wetlands.

Agricultural activity at the riparian wetlands in Indonesia was mostly limited to cultivation of one rice crop annually. Main constraints in increasing cropping intensity and crop diversity at riparian wetlands included: (1) unpredictable flooding occurrences and low soil quality (agronomic constraint), (2) low financial and technology adoption capacities of local smallholder farmers (economic constraint), and (3) public policies did not significantly escalate farmer's motivation to increase food production (social and institutional constraint).
Common bean (Phaseolus vulgaris L.) has been perceived as sensitive plant to excessive water condition. Aydogan and Turhan (2015) reported that waterlogging condition restricted leaf area enlargement, caused cell membrane injury, and altered stress-related enzyme activities. Lakitan et al. (1992) also reported that growth and yield of this bean plants were significantly suppressed after 4 days of flooding, especially if flooding was imposed during early reproductive growth period. This growth suppression was associated with decrease in leaf water potential, stomatal conductance, and photosynthesis. However, results of recent pot experiment indicated that common bean could tolerate shallow soil water table at depth around $13.5 \mathrm{~cm}$ below surface of growing substrate for up to 12 days as indicated by no significant reduction of pod yield, number of pods/plant, average pod weight, pod size, root dry weight, chlorophyll concentration index $(\mathrm{CCl})$, and relative leaf expansion rate (RLER) (Lakitan et al., 2018).

Moreover, Lakitan et al. (2018) observed that roots of common bean were unable to survive within water saturated condition below soil water table, but the plants were able to compensate for the root loss by increasing root biomass within aerobic substrate above water table. Oxygen 
and moisture availability at upper rhizosphere contributed to the ability of the bean plants to tolerate shallow water table. After termination of shallow water table treatment, common bean was able to regrow their roots into the previously water-saturated zone.

This field study was aimed to further justify the ability of common bean (Phaseolus vulgaris L.) in tolerating shallow soil water table condition, as an effort to intensify and diversify crop-grown at riparian wetland in Indonesia.

\section{Results}

There were some significant effects of soil water table depth on growth and yield parameters in common bean, as shown in Table 1. Effect of water table depth on plant height was more pronounced during early vegetative growth, i.e. the first three weeks. Significant effect of water table on number of leaves during 2 to 3 weeks after planting (WAP) was related to late development of trifoliate leaves. However, the water table treatments did not significantly affect $\mathrm{CCl}$ at the end of vegetative growth stage (4 WAP). In contrast, $\mathrm{CCl}$ was very significantly influenced by the treatment at late harvesting period (11 WAP).

Despite plant height did not differ amongst plants treated with different depth of water table at 4 WAP, there were significant differences in canopy diameter amongst those plants. This indicated that growth pattern in common bean used in this study had shifted from vertical to lateral growth. Based on number of harvested pods, yield difference amongst treated plants was more apparent during the first 4 weeks of harvesting period. However, difference in weekly fresh weight of harvested pods was only significant at 8 WAP. Roots as plant organ directly in contact with soil water table were the most obvious organ to be affected by the treatment. In this study, root length and number of primary lateral roots were very significantly affected but root dry weight was not. Shoot dry weight was very significantly influenced, but shoot/root ratio was not.

\section{Effects on vegetative growth}

Plant height and number of trifoliate leaves were weekly measured during vegetative growth stage as the main nondestructive indicators of growth progression. From opposite perspective, they can also be used as indicators of growth suppression due to unfavorable environment. In this study, plant height and number of trifoliate leaves developed during the first four weeks after planting were used to evaluate growth suppression in common bean associated with varied soil water table. Water table at $10 \mathrm{~cm}$ meter below soil surface consistently inhibited vertical growth and new leaf formation during the first three weeks. This inhibition was revealed by shorter and less leaf of plants exposed to soil water table at depth of $10 \mathrm{~cm}$, compared to those exposed at depth of $15 \mathrm{~cm}$ and $20 \mathrm{~cm}$ (Table 2). At 4 WAP, the differences were still noticeable but statistically non-significant. However, there were significant differences in diameter of the plant canopy amongst those exposed to different soil water table. Increase in diameter of the canopy represents increase in lateral or horizontal growth. This shifting of growth direction might be typical of the bushy-type bean, as the one used in this research. Structural canopy development started at 4 WAP was dominated by increase of side branches. The plants exposed to deeper $(20 \mathrm{~cm})$ soil water table expanded their canopy significantly larger than those exposed to water table at 15 $\mathrm{cm}$ depth. Furthermore, canopy of plants exposed to water table at $15 \mathrm{~cm}$ depth also larger than those exposed at 10 $\mathrm{cm}$ depth (Table 2 ).

\section{Effects on yield}

Bushy common bean used in this study commenced to produce flower buds during the fifth week and the young marketable pods were harvested during six weeks harvesting period, starting at 7 WAP. However, peak harvesting period was during 8 to 9 WAP (Fig 1A). Pod yields during the two-week peak period were $59.37 \%, 66.59 \%$, and $64.14 \%$ for common bean plants exposed to soil water table at depth of $10 \mathrm{~cm}, 15 \mathrm{~cm}$, and $20 \mathrm{~cm}$, respectively. Different effects of soil water table on pod yield were more evident during this two-week harvesting period. Pod yield of plants was more significantly suppressed by exposure to soil water table at depth of $10 \mathrm{~cm}$. Similar distribution pattern was observed on number of pods harvested (Fig 1B). Similar distribution pattern between pod yield and number of pods harvested indicated that yield was dependent on number of pods harvested, not due to differences on pod size or weight.

Total pod yield and number of pods harvested in plant exposed to water table at depth of $10 \mathrm{~cm}$ significantly lower than those exposed at depth of $15 \mathrm{~cm}$ and $20 \mathrm{~cm}$ (Table 3). Total yield and number of pods were mainly determined by differences at the two-week peak period since there were no significant amongst soil water table treatments at both ends of harvesting distribution curve, i.e. at 7 WAP of early harvest and at 10 to 12 WAP of late harvest. It should also be noted that variability on pod yield and number of pods amongst individual plants within each treatment was high at both ends of harvesting period, i.e. at 7 WAP and 12 WAP. At 7 WAP, this high variability was related to the fact that only few plants have started to produce marketable size pods. In contrast, at $12 \mathrm{WAP}$, in some plants, marketable size pods has all been harvested during the previous week.

$\mathrm{CCl}$ had been proven to be reliable for estimating leaf- $\mathrm{N}$ content and chlorophyll content. In this research, $\mathrm{CCls}$ were measured at near end of vegetative growth stage and at near end of harvesting period. Although the common bean plants were exposed to soil water table treatment during the vegetative growth stage, there was no significant different in CCls measured at 4 WAP. However, measurement at end of harvesting period (11 WAP) revealed that the CCls were significantly different amongst plants treated with different soil water table (Table 4).

\section{Effects on shoot/root ratio}

It was very logical that plants exposed to shallower soil water table, i.e. $10 \mathrm{~cm}$ below soil surface, was likely to had shorter roots. In this study, depth of soil water table was positively related to not only root length but also number of primary lateral roots. However, it had no significant effect on root dry weight (Table 5). In this case, logical explanation was the plants exposed to soil water table at depth of $10 \mathrm{~cm}$ 
Table 1. The F values of selected growth and yield parameters in common bean (Phaseolus vulgaris L.) exposed to different depth of soil water table.

\begin{tabular}{|c|c|c|c|}
\hline No. & Measured parameter & \multicolumn{2}{|c|}{ F-calculated } \\
\hline 1 & Plant height at 1 WAP & 17.43 & * \\
\hline 2 & Plant height at 2 WAP & 6.80 & * \\
\hline 3 & Plant height at 3 WAP & 7.55 & ** \\
\hline 4 & Plant height at 4 WAP & 2.67 & ns \\
\hline 5 & Number of leaves at 1 WAP & 0.93 & ns \\
\hline 6 & Number of leaves at 2 WAP & 13.98 & ${ }^{* *}$ \\
\hline 7 & Number of leaves at 3 WAP & 11.14 & ${ }^{* *}$ \\
\hline 8 & Number of leaves at 4 WAP & 1.58 & ns \\
\hline 9 & $\mathrm{CCl}$ at 4 WAP & 2.11 & ns \\
\hline 10 & $\mathrm{CCl}$ at $11 \mathrm{WAP}$ & 29.18 & ** \\
\hline 11 & Canopy diameter at 4 WAP & 18.41 & ${ }^{* *}$ \\
\hline 12 & Number of harvested pods at 7 WAP & 4.71 & ${ }^{*}$ \\
\hline 13 & Number of harvested pods at 8 WAP & 9.17 & ** \\
\hline 14 & Number of harvested pods at 9 WAP & 2.41 & ns \\
\hline 15 & Number of harvested pods at 10 WAP & 6.33 & ${ }^{*}$ \\
\hline 16 & Number of harvested pods at 11WAP & 0.04 & ns \\
\hline 17 & Number of harvested pods at 12 WAP & 1.17 & ns \\
\hline 18 & Total number of harvested pods & 5.85 & ${ }^{*}$ \\
\hline 19 & Fresh weight of harvested pods at 7 WAP & 2.20 & ns \\
\hline 20 & Fresh weight of harvested pods at 8 WAP & 10.67 & ${ }^{* *}$ \\
\hline 21 & Fresh weight of harvested pods at 9 WAP & 2.01 & ns \\
\hline 22 & Fresh weight of harvested pods at 10 WAP & 3.63 & ns \\
\hline 23 & Fresh weight of harvested pods at 11 WAP & 0.31 & ns \\
\hline 24 & Fresh weight of harvested pods at 12 WAP & 1.57 & ns \\
\hline 25 & Total fresh weight of harvested pods & 5.50 & ${ }^{*}$ \\
\hline 26 & Root length & 6.09 & ${ }^{* *}$ \\
\hline 27 & Number of primary lateral roots & 7.22 & ${ }^{* *}$ \\
\hline 28 & Root dry weight & 3.46 & ns \\
\hline 29 & Shoot dry weight & 10.74 & ${ }^{* *}$ \\
\hline 30 & Shoot/root ratio & 3.91 & $\mathrm{~ns}$ \\
\hline
\end{tabular}
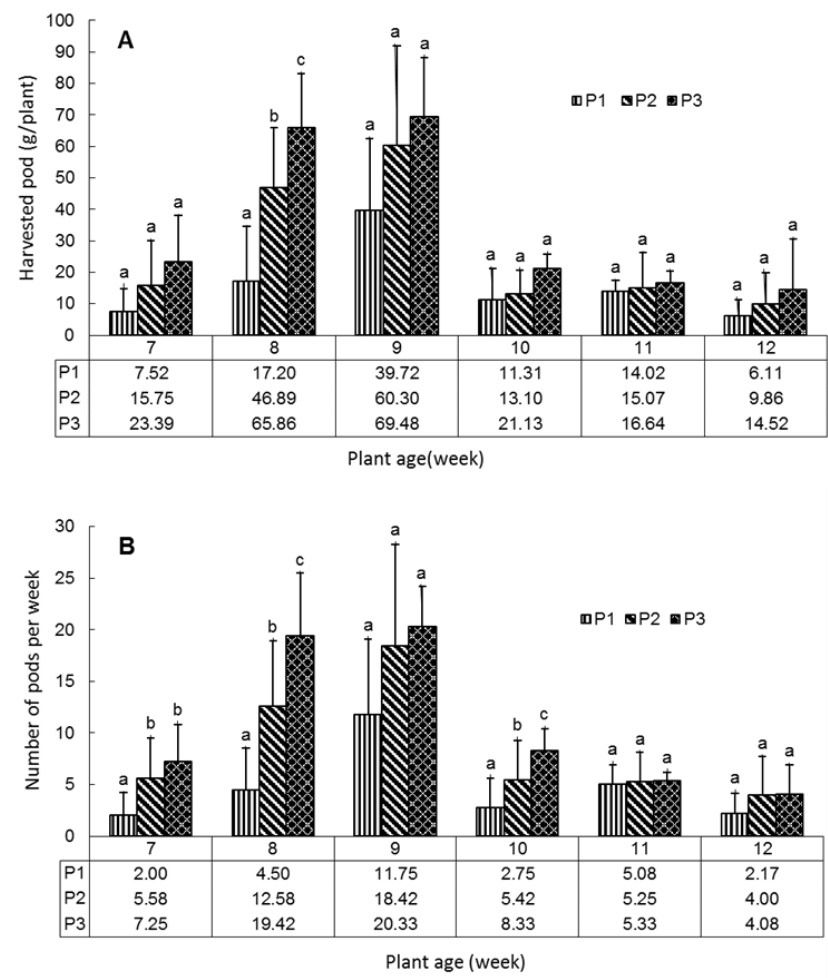

Fig 1. Weekly yield (A) and number of pods (B) of common bean (Phaseolus vulgaris L.) as affected by depth of soil water table. 
Table 2. Plant height, number of trifoliate leaves, and diameter of canopy in common bean (Phaseolus vulgaris L.) as affected by depth of soil water table during vegetative growth stage.

\begin{tabular}{|c|c|c|c|c|c|c|c|c|}
\hline \multirow{2}{*}{ Depth of Water Table $(\mathrm{cm})$} & \multicolumn{8}{|c|}{ Plant age (week) } \\
\hline & \multicolumn{2}{|c|}{1} & \multicolumn{2}{|l|}{2} & \multicolumn{2}{|l|}{3} & \multicolumn{2}{|l|}{4} \\
\hline & \multicolumn{8}{|c|}{ Plant Height $(\mathrm{cm})$} \\
\hline 10 & $6.08 \pm 1.13$ & $\mathrm{a}$ & $15.75 \pm 5.03$ & a & $34.00 \pm 12.12$ & a & $63.67 \pm 7.73$ & a \\
\hline 15 & $8.91 \pm 0.85$ & $b$ & $25.25 \pm 5.93$ & $b$ & $47.83 \pm 7.61$ & $b$ & $75.58 \pm 12.65$ & a \\
\hline \multirow[t]{2}{*}{20} & $9.08 \pm 0.82$ & $\mathrm{~b}$ & $24.62 \pm 4.24$ & $\mathrm{~b}$ & $48.41 \pm 6.00$ & $b$ & $75.92 \pm 11.31$ & a \\
\hline & \multicolumn{8}{|c|}{ Number of leaves } \\
\hline 10 & $1.66 \pm 0.52$ & a & $3.50 \pm 1.45$ & a & $7.17 \pm 1.57$ & a & $20.41 \pm 4.62$ & $\mathrm{a}$ \\
\hline 15 & $1.91 \pm 0.20$ & a & $6.08 \pm 0.97$ & $b$ & $12.58 \pm 3.32$ & $b$ & $23.91 \pm 5.57$ & a \\
\hline \multirow[t]{2}{*}{20} & $1.83 \pm 0.26$ & $\mathrm{a}$ & $6.50 \pm 0.63$ & $\mathrm{~b}$ & $15.33 \pm 2.88$ & c & $25.16+3.50$ & a \\
\hline & \multicolumn{8}{|c|}{ Diameter of canopy $(\mathrm{cm})$} \\
\hline 10 & n.m. & & n.m. & & n.m. & & $39.32 \pm 2.33$ & a \\
\hline 15 & n.m. & & n.m. & & n.m. & & $52.46 \pm 7.31$ & $b$ \\
\hline 20 & n.m. & & n.m. & & n.m. & & $61.42 \pm 6.55$ & c \\
\hline
\end{tabular}

Table 3. Cumulative yield and number of pods per plant in common bean (Phaseolus vulgaris L.) as affected by depth of soil water table during vegetative growth stage.

\begin{tabular}{lcccc}
\hline Depth of Water Table $(\mathrm{cm})$ & \multicolumn{2}{c}{ Total pod yield per plant } & \multicolumn{2}{c}{ Total number of pods per plant } \\
\hline 10 & $93.39 \pm 53.19$ & $\mathrm{a}$ & $28.08 \pm 14.62$ & $\mathrm{a}$ \\
15 & $162.03 \pm 79.53$ & $\mathrm{~b}$ & $51.25 \pm 25.98$ & $\mathrm{~b}$ \\
20 & $209.76 \pm 26.56$ & $\mathrm{~b}$ & $64.50 \pm 9.11$ & $\mathrm{~b}$ \\
\hline Note: Means followed by the same small letters within each column were not significantly different based on LSD at $\mathrm{p} \leq 0.05$. &
\end{tabular}

Table 4. Chlorophyll concentration index at vegetative (4 WAP) and reproductive (11 WAP) growth stage in common bean (Phaseolus vulgaris L.) as affected by depth of soil water table during vegetative and reproductive growth stage.

\begin{tabular}{|c|c|c|c|c|}
\hline Depth of Water Table $(\mathrm{cm})$ & \multicolumn{2}{|c|}{ Vegetative (4 WAP) } & \multicolumn{2}{|c|}{ Reproductive (11 WAP) } \\
\hline 10 & $28.59 \pm 1.59$ & a & $20.59 \pm 2.43$ & a \\
\hline 15 & $30.34 \pm 3.43$ & a & $24.343 \pm 1.55$ & $b$ \\
\hline 20 & $29.32 \pm 1.83$ & a & $28.66 \pm 2.10$ & c \\
\hline
\end{tabular}

Table 5. Root length, number of primary lateral root, root dry weight, shoot dry weight, and shoot/root ratio in common bean (Phaseolus vulgaris L.) as affected by depth of soil water table at the end of harvesting period.

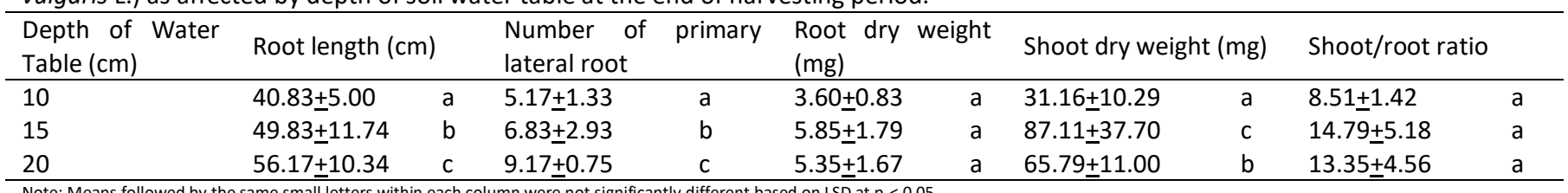

had shorter and less primary lateral roots but developed more massive secondary and tertiary root branching system. Severe impact of shallow soil water table (10 cm depth) was also observed on above ground organs. Shoot dry weight of common bean plants exposed to $10 \mathrm{~cm}$ depth water table limited to less than half of those exposed to $15 \mathrm{~cm}$ or $20 \mathrm{~cm}$ (Table 5). Shoot/root ratio was not significantly different amongst plants experienced different water table treatments. It implied that there was proportional growth suppression imposed on both shoot and roots.

\section{Discussion}

Growth of common bean during vegetative stage in field experiment was severely stunted if depth of soil water table was at $10 \mathrm{~cm}$ below soil surface as indicated by significantly shorter, less number of leaves, and smaller canopy diameter (Table 1). This stunted shoot growth is presumed to be associated with limited aerobic rhizosphere for roots to develop as indicated by shorter and less branching roots (Table 5). In previous pot experiment, shallow water table condition at depth around $13.5 \mathrm{~cm}$ or deeper for up to 12 days was tolerable by common bean as indicated by no significant reduction in root dry weight, $C C I, R L E R$, pod yield, number of pods/plant, average pod weight, and pod size (Lakitan et al., 2018). Based on results of these two experiments, it is fair to assume that critical depth of water table for common bean plant is between 10 and $13.5 \mathrm{~cm}$. Nonetheless, Meihana et al. (2017) reported that shallow water table was less harmful if the water table was at steady 
position. Under field condition, however, soil water table is more likely to fluctuate.

Soil section below water table was deficient in oxygen since soil pores are fully filled with water. Diffusion of oxygen in water was much slower than in air. Soil oxygen diffusion rates were below $20 \times 10^{-8} \mathrm{~g} \mathrm{~cm}^{-2} \mathrm{~min}^{-1}$ (Neira et al., 2015). Sauter (2013) argued that roots were the most prone and the first organ to suffer from oxygen shortage (hypoxia). Tolerant plants to hypoxic condition possessed one or more adaptive mechanisms, including their ability to mitigate and recover from the damaging effects by various adaptive strategies at cellular and metabolic levels (Ghosh and $\mathrm{Xu}$, 2014 ) or to initiate organogenesis to replace original root system with adventitious roots (Sauter, 2013). However, Lakitan et al. (1992) observed that common beans rarely developed adventitious roots under hypoxia, even for those that exhibited relatively more tolerant to this oxygen shortage condition.

Effects of shallow water table during vegetative growth stage on yield followed similar pattern. Cumulative yield of the bean plants exposed to soil water table at depth of 10 $\mathrm{cm}$ was significantly lower than those exposed to depth of 15 and $20 \mathrm{~cm}$ below soil surface (Table 3). More noticeable difference was observed during the first week of peak harvesting period, i.e. at 8 WAP (Fig 1). Celedonio et al. (2014) and Marti et al. (2015) identified that time around anthesis was the most susceptible period to waterlogging. Common bean was also more severely affected if the water table was imposed during flowering and pod setting stages (Ntukamazina et al., 2017). Duration of plants exposed to hypoxic condition was another factor influential magnitude of the stress impact (Kuai et al., 2015; Marti et al., 2015).

In this study, however, lower yield of bean plants exposed to shallower soil water table ( $10 \mathrm{~cm}$ below soil surface) was believed as carry-over effect during vegetative growth stage, because at the end of vegetative stage, soil water table was allowed to subside as the experimental plot gradually dried out. This argument was in line with findings of Pociecha (2013) in bean plants exposed to flooding stress. His finding indicated that reduction in growth was greater when flooding stress was applied at vegetative stage since the plants were not able to restore the physiological function to attain the optimal growth level after flooding. Khan et al. (2015) identified that pyruvate kinase, nucleotidylyl transferase, and beta-ketoacyl reductase played as key roles in post-flooding recovery in soybean hypocotyl by promoting glycolysis for generation of ATP and regulation of secondary metabolic pathways.

Mean of shoot/root ratio was lower in bean plants exposed to shallower soil water table, even if the value was statistically insignificant, masked by high variability in responses to the stress amongst individual plants (Table 5). This result indicated that growth and development of above ground organs were more severely affected by the shallow water table than roots. Ability of roots to regrow at the post-treatment period was a significant factor for overriding the negative effects of flooding on growth (Imaz et al., 2015). Since pod yield was also significantly decreased, then, these two factors contributed to lower shoot/root ratio at the end of harvesting period (12 WAP).

Liu et al. (2014) reported that flooding affected the allocation and transport of carbohydrate and nutrients. At 30 days of flooding, even though soluble sugar content in roots was increasing by $17.8 \%$, it cannot be concluded that the root soluble sugar was transported from leaves since at the same time soluble sugar content in leaves also increased by $20.2 \%$. Root biomass of flooded plants was $27.1 \%$ lower than non-flooded plants; therefore, absolute amount of soluble sugar in roots did not increase. It was more likely that increase in soluble sugar content was associated with breakdown of starch, since starch content in roots of flooded plants decreased by $48.9 \%$. Pociecha et al. (2016) found that resistant lines of winter rye allocated more sugars for cell wall composition in leaf and crown, thus less was transported out of leaf.

In conclusion, stress in common bean plants was more associated with depth of the water table than growth stage at which the stress was imposed. This argument was supported by finding in the field experiment that water table at position $10 \mathrm{~cm}$ below soil surface during vegetative phase caused significant reduction in growth and yield. Whereas, water table at position of $15 \mathrm{~cm}$ or deeper was able to be tolerated by the common bean plant. Common bean plant used in this study did not indicate its ability to develop aerenchyma or adventitious roots at stem base for compensating damages to main root system. Instead, it maintained normal growth by increasing root branching, indicated by higher number of primary lateral roots at deeper position of water table and enhancing root regrowth as water table subsided toward end of growing period.

\section{Materials and Methods}

\section{Plant materials}

Plant material used was common bean (Phaseolus vulgaris) variety of PV072. Seed preparation and planting procedures were similar to the pot experiment previously conducted (Lakitan et al., 2018).

\section{Location and time of the research conduction}

This field research was conducted on farmer's land within riparian wetland zone at Sungai Selincah Village, located in outskirt of Palembang, South Sumatra, Indonesia. The research area was flooded during rainy season and dried out during dry season. Land preparation and seed planting was conducted in May 2017 and last pod harvesting in August 2017 , i.e. during transition period from wet to dry season.

\section{Land preparation}

Raised beds are constructed by digging-and-elevating techniques. Therefore, constructing raised bed is also at the same time creating ditch side-by-side. Under shallow water table condition, the ditch is partially filled with water. In this condition, soil water table is directly measured based on vertical distance between water surface in the ditch and upper surface of the raised bed. This procedure was used in constructing the $10-\mathrm{cm}, 15-\mathrm{cm}$, and $20-\mathrm{cm}$ raised beds. Position of water surface in the ditch was level to soil water table underneath surface of the raised beds. Water level in the ditch was controlled by positioning water outlet for each treatment accordingly. Raised beds used local alluvial soil, pH 5.5-6.5, low nutrient and organic matters. 
Fertilizer used was chicken manure and no inorganic fertilizer was used. As base fertilizer application, upper soil layer to depth of $10 \mathrm{~cm}$ of all raised beds were mixed with chicken manure at dose of 15 tons per hectare. Two rows of silver-colored plastic mulch were laid along the length of raised bed for conserving soil moisture and producing clean vegetable products. Holes spaced at $70 \mathrm{~cm}$ were made along the length of the mulch. Seeds were planted through each hole. At 4 weeks after planting, water in the ditch was allowed to drain naturally. Therefore, the bean plants were only exposed to stagnant shallow water table treatments during the first 4 weeks of their life cycle, i.e. during vegetative growth stage.

\section{Data collection}

Experimental design of 3 treatments and 6 replications in this research was arranged in Randomized Block Design (RBD). The treatments were consisted of 3 different depth of water table, i.e. $10 \mathrm{~cm}, 15 \mathrm{~cm}$ and $20 \mathrm{~cm}$ below soil surface. Plant height and number of trifoliate leaf were monitored during the first 4 weeks of vegetative growth stage; CCl (using Chlorophyll Meter Konica Minolta SPAD502 Plus) and canopy diameter were measured at 4 weeks after planting (WAP); number and fresh weight of young pods were daily harvested and measured during period of 7 to 12 WAP. Leaf length and width measurements and destructive sampling for measuring dry weights were done during 1 to 4 WAP. Leaf area estimation based on linear measurements of leaf length and/or leaf width was done following leaf area estimation models of Lakitan et al. (2017). Plant materials were separated into root, leaf, and stem. For dry weight measurement, plant samples weed dried in an oven at temperature of $70^{\circ} \mathrm{C}$ for 48 hours. Dried plant materials were weighted using digital scale.

\section{Data analysis}

Collected data were analyzed using Analysis of Variance based on Randomized Block Design. If the treatment effect was significant at $p<0.05$, then the difference amongst treatments were further tested using Least Significant Difference (LSD) at $p<0.05$ and $p<0.01$.

\section{Conclusion}

Even though common bean was usually categorized as susceptible vegetable crop to waterlogging or shallow water table, recent findings from field research indicated that common bean could tolerate shallow water table positioned at $15 \mathrm{~cm}$ below soil surface or lower. There was no significant differences in growth and yield amongst common bean plants exposed to water table at $15 \mathrm{~cm}$ or deeper. In contrast, the plants exposed to water table at $10 \mathrm{~cm}$ depth exhibited significant reduction in some growth parameters including plant height, canopy diameter, number of trifoliate leaves, root length, number of primary lateral roots, shoot dry weight, and $\mathrm{CCl}$ during reproductive stage. Moreover, cumulative yield and total number of pods were also suppressed by water table at depth of $10 \mathrm{~cm}$.

\section{Acknowledgments}

This work was supported by the Program Penelitian Unggulan Profesi 2017 Universitas Sriwijaya (SK No.0570/UN9/PP/2017). We would like to express our appreciation to the editor-in-chief of this journal for their superb helps and guidance; and also to unanimous reviewers for their comments and suggestions for improving scientific quality of this article.

\section{References}

Aydogan C, Turhan E (2015) Changes in morphological and physiological traits and stress-related enzyme activities of green bean (Phaseolus vulgaris). Hort Environ Biotech. 56(3): 391-401.

Celedonio RPS, Abeledo LG, Miralles DJ (2014) Identifying the critical period for waterlogging on yield and its components in wheat and barley. Plant Soil 378: 265-277.

Fan Y, Li H, Miguez-Macho G (2013) Global patterns of groundwater table depth. Science. 339: 940-943.

Ghosh D, Xu J (2014) Abiotic stress responses in plant roots: a proteomics perspective. Frontiers Plant Sci. 5. doi:10.3389/fpls.2014.00006.

Imaz JA, Giménez DO, Grimoldi AA, Striker GG (2015) Ability to recover overrides the negative effects of flooding on growth of tropical grasses Chloris gayana and Panicum coloratum. Crop Pasture Sci. 66(1): 100-106.

Khan MN, Sakata K, Komatsu S (2015) Proteomic analysis of soybean hypocotyl during recovery after flooding stress. J Proteomics. 121: 15-27.

Kuai J, Zhoua Z, Wanga Y, Menga Y, Chena B, Zhao W (2015) The effects of short-term waterlogging on the lint yield and yield components of cotton with respect to boll position. Europ J Agronomy. 67: 61-74.

Lakitan B, Kadir S, Wijaya A, Susilawati (2018) Tolerance of common bean (Phaseolus vulgaris L.) to different durations of simulated shallow water table condition. Aust J Crop Sci. 12(4): 661-668.

Lakitan B, Widuri LI, Meihana M (2017) Simplifying procedure for a non-destructive, inexpensive, yet accurate leaf area estimation in snap bean (Phaseolus vulgaris). J Appl Hort. 19(1): 15-21.

Lakitan B, Wolfe DW, Zobel RW (1992) Flooding affects snap bean yield and genotypic variation in leaf gas exchange and root growth response. J Amer Soc Hort Sci. 117(5): 711-716.

Liu Z, Cheng R, Xiao W, Guo Q, Wang N (2014) Effect of OffSeason Flooding on Growth, Photosynthesis, Carbohydrate Partitioning, and Nutrient Uptake in Distylium chinense. PLoS One 9(9): e107636.

Margono BA, Bwangoy JRB, Potapov PV, Hansen MC (2014) Mapping wetlands in Indonesia using Landsat and PALSAR data-sets and derived topographical indices. Geo-spatial Inform Sci. 17(1): 60-71.

Marti J, Savin R, Slafer GA (2015) Wheat yield as affected by length of exposure to waterlogging during stem elongation. J Agro Crop Sci. 201(6): 473-486.

Meihana M, Lakitan B, Susilawati, Harun MU, Widuri LI, Kartika K, Siaga E, Kriswantoro H (2017) Steady shallow water table did not decrease leaf expansion rate, specific leaf weight, and specific leaf water content in tomato plants. Aust J Crop Sci. 11(12): 1635-1641. 
Neira J, Ortiz M, Morales L, Acevedo E (2015) Oxygen diffusion in soils: Understanding the factors and processes needed for modeling. Chilean J Agric Res. 75: 35-44.

Ntukamazina N, Onwonga RN, Sommer R, Mukankusi CM, Mburu J, Rubyogo JC (2017) Effect of excessive and minimal soil moisture stress on agronomic performance of bush and climbing bean (Phaseolus vulgaris L.). Cogent Food Agric. 3(1): 1373414. doi:
Pociecha, E (2013) Different Physiological Reactions at Vegetative and Generative Stage of Development of Field Bean Plants Exposed to Flooding and Undergoing Recovery. J Agro Crop Sci. 199(3): 195-199.

Pociecha E, Rapacz M, Dziurka M, Kolasińska I (2016) Mechanisms involved in the regulation of photosynthetic efficiency and carbohydrate partitioning in response to low-and high-temperature flooding triggered in winter rye (Secale cereale) lines with distinct pink snow mold resistances. Plant Physiol Biochem. 104: 45-53.

Sauter M (2013) Root responses to flooding. Curr Opin Plant Biol. 16(3): 282-286. 